\title{
A Comprehensive In Silico Study for the Identification of Therapeutic Target Against Peripheral Neuropathic Pain in humans
}

\author{
Sagar Bhowmik ${ }^{\mathrm{a}^{*}}$, Sheikh Mohiuddin Samrat $^{\mathrm{a}}$ and Debneela Paul ${ }^{\mathrm{b}}$ \\ ${ }^{a}$ Discipline of Biotechnology and Genetic Engineering, Khulna University, Khulna 9208, Bangladesh. \\ ${ }^{b}$ Department of Applied Chemistry and Chemical Engineering, University of Rajshahi, Rajshahi 6205, Bangladesh.
}

\begin{abstract}
:
Background: VGF (non-acronymic) is a neuropeptide precursor or neuro-protein or neurosecretory protein which plays vital roles in the regulation of gastric contractility, mood regulation, and peripheral neuropathic pain and possibly, cancer.

Objective: VGF may be a potential target as it has a unique contribution to the development of neuropathic pain which is a target for Oxymatrine (OMTR).

Method: Based on this, we have endeavored to discover VGF inhibitors from the ChEMBL database of Oxymatrine (OMTR) analogues by employing homology modelling, molecular docking and pharmacophore analysis.

Result: Our in silico investigation reveals that 13-Methoxymatrine has desired characteristics for becoming a future formulation. Conclusion: To confirm the efficacy of this compound, essential animal and clinical trials are needed to be performed. We believe that our present study will help to find an efficient and effective therapy for treating neuropathic pain in human which is modulated by VGF.

Keywords: Neuropathic pain, VGF, OMTR, Homology modelling, Molecular docking, Pharmacophore analysis.
\end{abstract}

\section{INTRODUCTION}

VGF (nonacronymic) is a neurotrophin-inducible neuropeptide precursor that has potent antidepressant-like actions and regulates energy metabolism [1-5], two actions that might be related. VGF, expressed abundantly in neurons and some neuroendocrine cells, is cleaved by proteases into smaller peptides like TLQP-21, TLQP-62 that are subsequently secreted. Due to the presence of paired basic amino acid residues ( $\mathrm{R}-$ Arginine, and $\mathrm{K}-$ Lysine), the VGF sequence undergoes endoproteolytic cleavage to produce several smaller peptides, released upon stimulation via the regulated secretory pathway both in vitro and in vivo. There are data suggesting that the VGF-derived peptides are the biologically active, stored in dense core vesicles and secreted in order to play a role in inter cellular communication, and responsible for the diverse range of biological functions associated with VGF like energy balance, re- productive behavior, pain modulation, mood order, etc. $[1,6]$. Heat shock cognate protein A8 (HSPA8) has been found as a receptor of VGF derived bioactive peptide TLQP-21 in SH- SY5Y cells.
*Address correspondence to this author at the Department of Biotechnology and Genetic Engineering, Khulna University, Khulna, Bangladesh; Tel: +88-01303-222724.

E-mail: ibhowmik49@gmail.com

So, it was of much interest to observe whether Oxymatrine (OMTR), an inhibitor of HSPA8, inhibits the binding of TLQP-21 to the surface of live SH-SY5Y cells. The results confirmed, as expected, that OMTR reduces the binding of TLQP- 21 to the surface of live SH-SY5Y cells, with a strong conclusion that the binding of TLQP-21 to the surface of SH-SY5Y cell model was through HSPA8 [7, 8]. HSPA8 $(71 \mathrm{kDa})$, a constitutively expressed protein, is a fascinating member of the HSP70 family. HSPA8 expressing on the cell surface performed as a cellular receptor [7, 8]. Over 70 candidate compounds were screened for HSPA8 inhibitor. Among the compounds examined, Oxymatrine (OMTR, matrine oxide, matrine $\mathrm{N}$ oxide, matrine 1- oxide: one of many quinolizidine alkaloid compounds), molecular weight (MW) 264.31, an alkaloid extracted from Sophera flavescens [9] (popularly known as KuShen plant), showed significant activity to down regulate the expression of HSPA8 in HepG2 liver cells without showing any toxicity to the cells. Additionally, 
Western blotting confirmed the reducing effect at the protein level, showing reduction of HSPA8 protein in the OMTR treated cells [10]. Use of active sitetargeting inhibitor is an effective approach leading to pharmacological inventions. The inhibition efficacy of OMTR potentiates its application in drug targeting. On the other hand, VGF contributes to the modulation of pain through activation of primary microglia and potentially involve interactions with components of the complement system. The findings highlight the importance of VGF in the research of conception and could lead to new perspectives and targets for pain therapeutics. Considering all these, the study here was undertaken to ascertain VGF inhibitors from the ChEMBL database of Oxymatrine (OMTR) analogues in silico.

\section{METHODOLOGY}

2.1. Homology Modeling, Model validation and Prediction of Active Site

The protein primary sequence of VGF (vascular growth factor) was retrieved from NCBI database [11] and NCBI-BLAST (Basic Local Alignment Search Tool) [12] was used for the identification of suitable templates for homology modeling of VGF. The homology model was built by EasyModeller ver 4.0 [13], SWISS-MODEL [14-16] and CPH MODEL [17]. The generated models were validated by VERIFY3D server [18] which uses threedimensional profiles for assessing protein models and SWISS-MODEL workspace of ExPASY server [19] for PROCHECK [20] and QMEAN6 (Qualitative Model Energy Analysis) [21] value. PROCHECK assesses the stereochemical quality of a protein structure and QMEAN stands for Qualitative Model Energy Analysis, is a composite scoring function describing the major geometrical aspects of protein structures. After analyzing the data from server, the best suitable model is selected. The modeled structure and templates were superimposed by UCSF Chimera ver 1.12 [22]. The active site residues which will play an important role in protein-ligand interaction were identified by the $\mathrm{COACH}$ server [23].

\subsection{Virtual screening for the retrieval of potentially active compounds}

ChEMBL server [24] which is now a wellestablished resource in the fields of drug discovery and medicinal chemistry research. The ChEMBL database curates and stores standardized bioactivity, molecule, target and drug data containing 2,101,843 compounds. This server was employed for finding structural analogous of Oxymatrine using 70\% similarity threshold search and 22 compounds were found. These compounds were submitted to SwissADME server [25] and screened based on Ghose violations [6, 26-29]. After the primary screening, all of the compounds were submitted to PASS (prediction of activity spectra for substances) prediction server [30] which predicts the possibility of active (Pa) and inactive (Pi) value for identifying potent compounds which have antimycobacterial activity. Based on $\mathrm{Pa}$ and $\mathrm{Pi}$ value from PASS server and toxicity profile (mutagenic, tumorigenic, reproductive, irritant effect) in accordance with a good drug-likeness score by DataWarrior software [31], 5 leads were selected for further study.

\subsection{Molecular Docking}

The selected ligands and protein model were optimized by UCSF Chimera ver 1.12 [22] before docking was performed. Docking was performed by AutoDock Vina ver. 1.1.2 [32] which predicts the interaction between ligands and bio macromolecular targets. Before docking, polar hydrogens were added to the Protein model of VGF by Autodock tools and initial parameters were assigned for the protein molecule. For the compounds, the torsions were fixed by Autodock tools and both the protein and compounds were saved as PDBQT file format. The grid (grid size $-98 * 92 * 78$ ) was fixed around the active site which was obtained from $\mathrm{COACH}$ server. On 6 different poses, the binding energy of the protein and ligands were obtained and the best binding energy was chosen for further analysis. LIGPLOT [33] was employed for presenting the twodimensional interaction between protein and ligands. Pymol [34, 35] was employed for presenting the three-dimensional interaction between protein and ligands.

\subsection{Molecular properties and Oral toxicity prediction}

The pharmacokinetics, ADME and toxicity properties of the lead compound were estimated using SwissADME [25] and PreADMET [36].

\section{RESULT and DISCUSSION}

CADD or computer-aided drug discovery requires to perform three main tasks, namely, prediction of the three-dimensional structure of the protein, prediction of the possible interaction between protein and ligands by docking and finally, testing biological and pharmacophore properties of the lead which was targeted as potential drug [37]. The following is performed in this study to carry out the research.

\subsection{Homology Modeling, Model Validation and Prediction of Active Site}

The absence of three-dimensional (3D) structure of 
A comprehensive study against Neuropathic Pain in human

VGF (vascular growth factor) in the public database, instigated us to build a 3D structure using homology modelling method by SWISS-MODEL, CPH Model and EasyModeller. From analyzing the data from PROCHECK, VERIFY3D and QMEAN6; model generated from EasyModeller is proved to the best suitable for our purpose. EasyModeller uses two templates (3j83.1A) and (2I1J. A) which have $34.62 \%$ and $26.47 \%$ sequence identity respectively. Subsequently, VERIFY3D server showed that the modelled structure had $48.48 \%$ residues had an averaged 3D-1D score $>=0.2$. PROCHECK showed that $87 \%$ and $9.2 \%$ residues in the most favored and additional allowed region respectively according to Psi (degrees) and Phi (degrees) and 1.6\% residues in the disallowed region in the Ramachandran Plot
Figure 4. QMEAN6 showed that z-score is -10.12 Figure 5. COACH server predicted 10, 200, 204, 208, 211, 242, 245, 246, 293, 296, 314,315, 318, 319, 321, $335,340,345,353,356,359,363,365,366,367$, $368,376,405$ and 408 residues as potential active site residue. For designing a drug, homology modeling is a reliable as well as quick method for obtaining a protein model which is currently unavailable in the present databases [38-40]. It is opined that if any proteins don't have structural information then the model of that protein can be built by homologous proteins or templates which have at least 30\% sequence identity [41]. In this study, the templates have more than $30 \%$ sequence identity Table 1 which is highly reliable for constructing a model based on the template.

Table 1. Templates used for homology modeling of VGF.

\begin{tabular}{|c|c|c|c|}
\hline PDB ID & DESCRIPTION & IDENTITY (\%) & $\begin{array}{l}\text { QUERY COVER } \\
(\%)\end{array}$ \\
\hline $3 \mathrm{j} 83 \mathrm{1A}$ & $\begin{array}{c}\text { Heptameric EspB Rosetta model guided by EM } \\
\text { density }\end{array}$ & 34.62 & 52.5 \\
\hline 2I1J A & $\begin{array}{l}\text { Moesin from Spodoptera frugiperda at } 2.1 \\
\text { angstroms resolution }\end{array}$ & 26.47 & 42.3 \\
\hline
\end{tabular}

From Ramachandran Plot and VERIFY3D, it is transparent that the built model was valid. Additionally, in QMEAN6 validated the modeled structure based on six structural descriptors. The modeled structure and the superimposed structure of generated model and template showed that the model was correct. The modeled structure and the superimposed structure of generated model and template are shown in Figures 1, 2, 3, 6, 7 and 8.

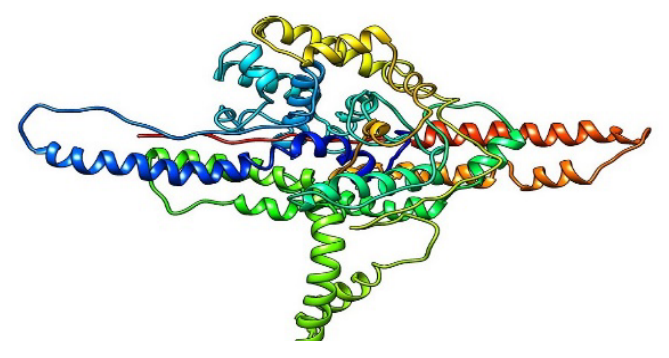

Fig. 1 The modeled protein in ribbon style. 
bioRxiv preprint doi: https://doi org/10.1101/2021.11.03 467110. this version posted November 4, 2021. The copyright holder for this preprint (which was not certified by peer review) is the author/funder, who has granted bioRxiv a license to display the preprint in perpetuity. It is made available under aCC-BY 4.0 International license.

A comprehensive study against Neuropathic Pain in human

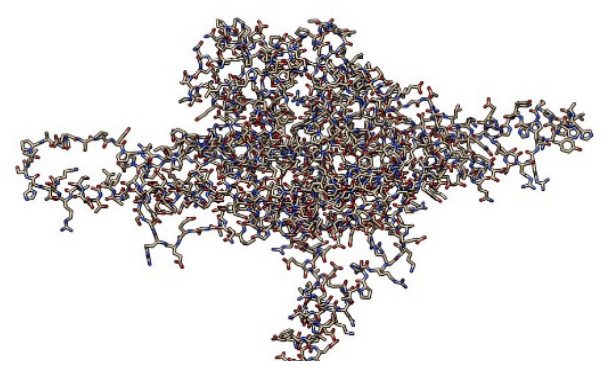

Fig. 2 The modeled protein in wireframe style.

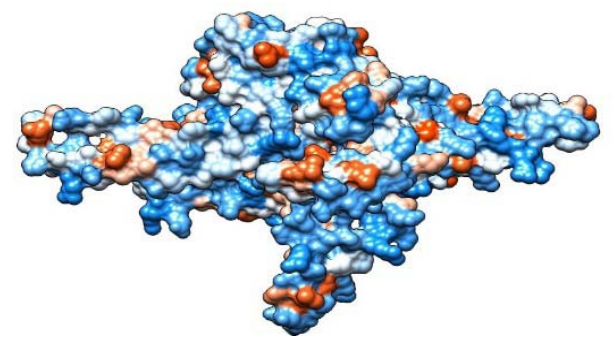

Fig. 3 The modeled protein in hydrophobicity surface style.

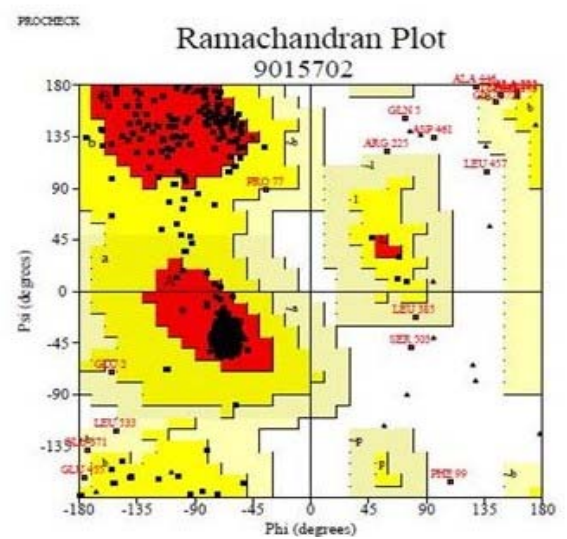

Fig. 4 Ramachandran plot of modeled structure validated by PROCHECK server.

Table 2. Ramachandran plot statistics for generated protein model.

\begin{tabular}{|c|c|c|}
\hline Ramachandran plot statistics & Residues & $\%$ \\
\hline Residues in most favoured regions [A, B, L] & 387 & 87 \\
\hline Residues in additional allowed regions [a,b,l,p] & 41 & 9.2 \\
\hline Residues in generously allowed regions [ a, $\sim \mathrm{b}, \sim 1, \sim \mathrm{p}]$ & 10 & 1.6 \\
\hline Residues in disallowed regions & 7 & 100 \\
\hline Number of non-glycine and non-proline residues & 0 & \\
\hline Number of end-residues (excl. Gly and Pro) & 34 & \\
\hline Number of glycine residues (shown as triangles) & 66 & \\
\hline Number of proline residues & 545 & \\
\hline Total number of residues & & \\
\hline
\end{tabular}


bioRxiv preprint doi: https://doi. org/10.1101/2021.11.03 467110: this version posted November 42021 . The copyright holder for this preprint (which was not certified by peer review) is the author/funder, who has granted bioRxiv a license to display the preprint in perpetuity. It is made available under aCC-BY 4.0 International license.

A comprehensive study against Neuropathic Pain in human

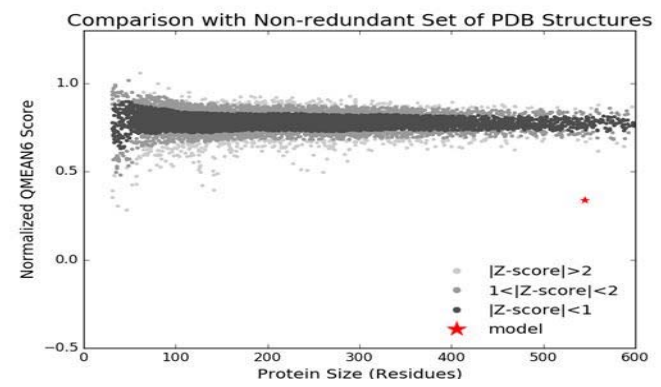

Fig. 5 Validation of the modeled structure by QMEAN6.

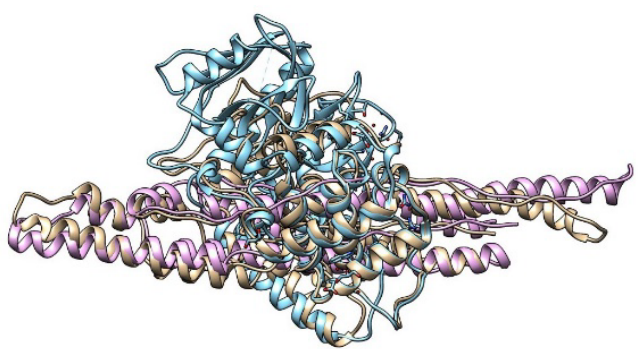

Fig. 6 Superimposed structure of the modeled protein and templates.

Fig. 7 Superimposed structure of the modeled protein (blue color) and template (3j83.1. A) (red color).

Table 3. Root mean square deviation (RMSD) between VGF model and template (3j83.1. A).

\begin{tabular}{|c|c|}
\hline Name & RMSD Value \\
\hline VGF Protein model & \multirow{2}{*}{1.169 angstroms; (across all 256 pairs) } \\
\hline 3j83.1. A & \\
\hline
\end{tabular}

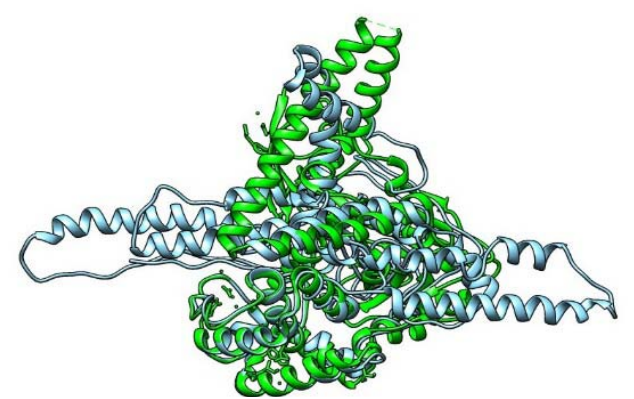

Fig. 8 Superimposed structure of the modeled protein (blue color) and template(2i1j.pdb) (green color).

Table 4. Root mean square deviation (RMSD) between VGF model and template (2i1j). 
bioRxiv preprint doi: https://doi.org/10.1101/2021.11.03.467110; this version posted November 4, 2021. The copyright holder for this preprint (which was not certified by peer review) is the author/funder, who has granted bioRxiv a license to display the preprint in perpetuity. It is made available under aCC-BY 4.0 International license.

A comprehensive study against Neuropathic Pain in human

\begin{tabular}{|c|c|}
\hline Name & RMSD Value \\
\hline VGF Protein model & 0.649 angstroms; (across all 341 pairs) \\
\hline $2 \mathrm{i} 1 \mathrm{j}$ & \\
\hline
\end{tabular}

\subsection{Virtual screening for the retrieval of potentially active compounds}

Based on similarity search in ChEMBL, 22 compounds were found among which 7 compounds followed Ghose rule, Lipinski rule, Veber rule, Egan rule and Muegge rule and selected for future work. Among these 7 compounds, 6 compounds which had a good antimycobacterial activity were selected based on higher Pa value compared to lower Pi value from PASS prediction server. Compounds which didn't show any mutagenic, tumorigenic, reproductive, irritant effect and had a good drug- likeness score were finalized as leads and by this, 5 leads were found.

ChEMBL is an Open Data database which contains more than one million compounds especially for the drug discovery and chemical biology research [24]. From this database, 22 compounds of Oxymatrine were primarily screened which followed five rules which are used for screening leads currently. Oxymatrine was selected as the mother ligand because of this ligand functions as the inhibitory agent against VGF [7] and this neuropeptide VGF (a non-acronymic name) is responsible in the regulation of neuropathic pain in human [42]. Ghose's rule [26, 43] explained that a compound should have calculated $\log \mathrm{P}$ between -0.4 and 5.6, molecular weight between 160 and 480, molar refractivity between 40 and 130 and a total number of atoms between 20 and 70. Lipinski's rules [27] limit various parameters as molecular weight $\leq 500, \mathrm{H}$ bond acceptors $\leq 10$, H-bond donors $\leq 5$, calculated $\log \mathrm{P}(\mathrm{C} \log \mathrm{P}) \leq 5$. Ve- ber's rules [6] limit only two criteria for oral bioavailability for the drug candidates and they are rotatable bonds $\leq$ 10 and po- lar surface area $\leq 140 \mathrm{~A}^{02}$ (or H-bond donors and acceptors $\leq 12$ ). Egan's rule [28] is defined by total polar surface area (TPSA) > $131.6 \AA ̊$ or $\log \mathrm{P}>5.88$. Muegge's rule [44] defines two pharmacophore filter (PF1 and PF2) in addition to some additional rules which discriminate between drug and nondrug molecules. For finding the accurate compounds as leads we ap- plied all of these rules for screening and it was found that only 7 compounds followed these rules. Because for making dis- crimination between non-drugs and drugs molecule, the rule of five cannot be employed. Physico-chemical parameters are may be required but are not effective features of a drug-like compound and Physico-chemical parameters cannot singly ascertain a drug molecule. For this, in the later phase of the drug discovery practice, other cogent aptitudes in crucial parameters like the halflife of analogs of lead molecules and oral bioavailability are accepted as standard among scientists. Thus, endeavors are given on other experimental data including membrane affinity, plasma exposure, and protein binding or aqueous solubility for correlating with counting parameters, for example, rule- of-five [29]. Based on the higher value of $\mathrm{Pa}$ compared to $\mathrm{Pi}, 6$ compounds were selected which have better antimycobacterial activity. From DataWarrior software, it was found that only 5 compounds didn't have any type of toxicity and had a good drug-likeness score. The term 'drug-like' is used by a little of variety by a number of authors [45-47]. Drug-likeness is defined commonly as a descriptor in a statistical way which is resultant from the catalogs of other compounds [29]. These 5 compounds are considered as leads. Leads categorized into three classes, first, lowaffinity $(>0.1 \mu \mathrm{m})$ compounds with low ClogP and MW. By the optimization of pharmacokinetic profile and potency, these are turned into drugs. The second type of leads have high molecular weight and affinity and a number of drugs are included in this class. Finally, the last class of leads has druglike ClogP (3-5) and MW (300-500) with low affinity [48].

\subsection{Molecular Docking}

Molecular docking paves the way for studying the mechanism of interaction between protein and compounds [49]. Higher efficacy between drug and protein could be indicated by the higher binding affinity [50]. After optimization by UCSF Chimera, leads and Benzodiazepine were docked with protein by using AutoDock Vina ver. 1.1.2.

Analysis of the docking result was done focusing mainly on three main points, i.e. binding energy $(\mathrm{kcal} / \mathrm{mol})$, number of $\mathrm{H}$-bonds and interacting amino acids. In the case of molecular docking, the best binding energy between protein and ligand is indicated by the highest negative value and vice versa [51]. From Table 5, it is clear that compound 
A comprehensive study against Neuropathic Pain in human

with 13-Methoxymatrine (CHEMBL1672134) showed the highest binding affinity towards the target protein being analyzed. The interaction between protein and leads are shown in (twodimensional) Figures 10,11, 12, 13, 14 and 15 and (three-dimensional) Figures 16, 17, 18, 19, 20 and 21 and the interaction between protein and top lead is shown in Figures 22, 23 and 24. Interestingly, it was found that 13-Methoxymatrine had a good antimycobacterial as well as antibacterial activity. Table 6 shows the physical properties of the 13Methoxymatrine compound. It is suggested that a ligand to be an ideal one should have the minimum docking score and must satisfy drug-likeness parameters [52]. Our selected ligand satisfied both of these criteria in accordance with having no mutagenic, tumorigenic, reproductive and irritant effect which follows Ghose's rule, Lipinski's rule, Veber's rule and Egan's rule containing a good antimycobacterial as well as antibacterial activity. So, 13-Methoxymatrine can be regarded as the final lead for becoming a potential drug for treating neuropathic pain by VGF.

Table 5. Binding energy and interacted amino acids of different compounds with the target protein.

\begin{tabular}{|c|c|c|c|}
\hline Compound & $\begin{array}{c}\text { Interacted amino acids } \\
\text { (H bonds only) }\end{array}$ & $\begin{array}{c}\text { Binding } \\
\text { energy } \\
\text { (kcal/mol) }\end{array}$ \\
\hline Oxymatrine & None & Ser 182, Lys 185, Arg 210, Met & 377 \\
\hline $\begin{array}{c}\text { 9alpha-Hydroxymatrine } \\
\text { (CHEMBL204747) }\end{array}$ & Ser 183 & Ser 183, Pro 184, Arg 447, Asp & -5.0 \\
\hline $\begin{array}{c}\text { 14beta-Hydroxymatrine } \\
\text { (CHEMBL3590539) }\end{array}$ & None & Ser 182, Lys 185, Asp 378, Pro & -4.9 \\
\hline $\begin{array}{c}\text { 9alpha-Hydroxy-13,14- } \\
\text { didehydromatridine-15- } \\
\text { one (CHEMBL382625) }\end{array}$ & Arg 210 & Ser 182, Lys 185, Gln 376, Met & -4.7 \\
\hline $\begin{array}{c}\text { 13-Hydroxymatrine } \\
\text { (CHEMBL1672133) }\end{array}$ & None & Gly 180, Ser 182, Ile 386, Pro 378 & -5.4 \\
\hline $\begin{array}{c}\text { 13-Methoxymatrine } \\
\text { (CHEMBL1672134) }\end{array}$ & Ser 182 & $\begin{array}{c}\text { Glu 179, Gly 180, Ser 182, Ser } \\
\text { 384, Ile 386, Pro 441, Ala 444 }\end{array}$ & -5.0 \\
\hline
\end{tabular}

Table 6. Physical properties of the top ranked molecule (13-Methoxymatrine).

\begin{tabular}{|c|c|}
\hline Physical Properties & 13-Methoxymatrine \\
\hline ChEMBL ID & CHEMBL1672134 \\
\hline PubChem CID & 53322793 \\
\hline Formula & $\mathrm{C}_{16} \mathrm{H}_{26} \mathrm{~N}_{2} \mathrm{O}_{2}$ \\
\hline Molecular Weight & $278.396 \mathrm{~g} / \mathrm{mol}$ \\
\hline Hydrogen Bond Donor Count & 0 \\
\hline Hydrogen Bond Accept Count & 3 \\
\hline Rotatable Bond Count & 1 \\
\hline Topological Polar Surface Area & $32.8 \mathrm{~A}^{\wedge} 2$ \\
\hline XLogP3-AA & 1.1 \\
\hline Heavy Atom Count & 20 \\
\hline
\end{tabular}


bioRxiv preprint doi: https://doi.org/10.1101/2021.11.03.467110; this version posted November 4, 2021. The copyright holder for this preprint (which was not certified by peer review) is the author/funder, who has granted bioRxiv a license to display the preprint in perpetuity. It is made available under aCC-BY 4.0 International license.

A comprehensive study against Neuropathic Pain in human

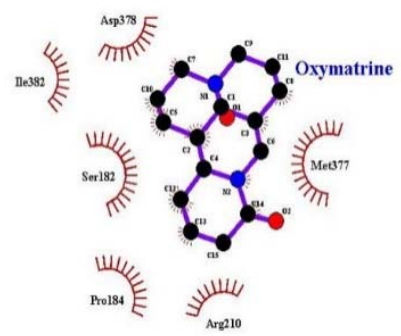

Fig. 9 2D interaction between protein and Oxymatrine.

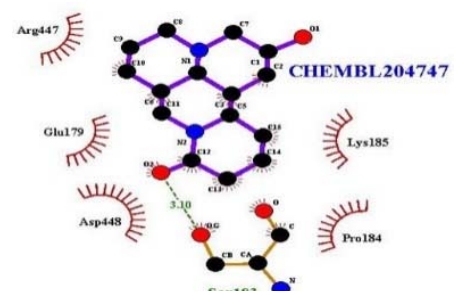

Fig. 10 2D interaction between protein and 9alpha-Hydroxymatrine (CHEMBL204747).

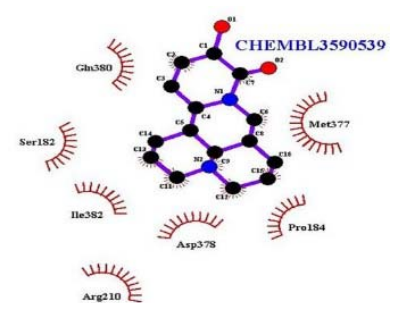

Fig. 112 D interaction between protein and 14beta-Hydroxymatrine (CHEMBL3590539).

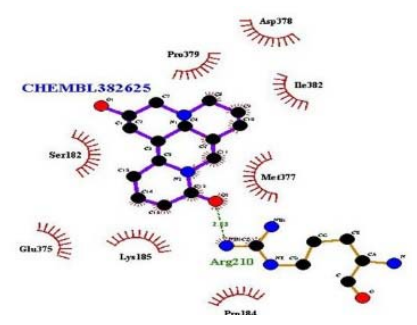

Fig. 12 2D interaction between protein and 9alpha-Hydroxy-13,14-didehydromatridine-15-one (CHEMBL382625).

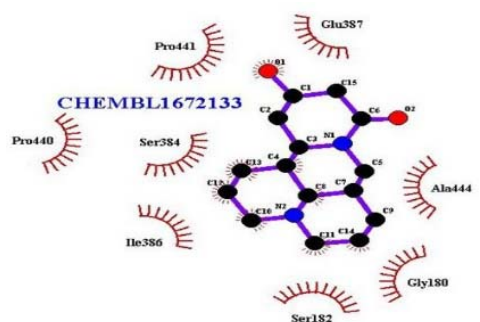

Fig. 13 2D interaction between protein and 13-Hydroxymatrine (CHEMBL1672133). 
bioRxiv preprint doi: https://doi.org/10.1101/2021.11.03.467110; this version posted November 4, 2021. The copyright holder for this preprint (which was not certified by peer review) is the author/funder, who has granted bioRxiv a license to display the preprint in perpetuity. It is made available under aCC-BY 4.0 International license.

A comprehensive study against Neuropathic Pain in human

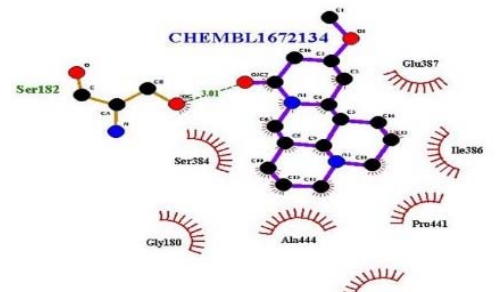

sylue

Fig. 14 2D interaction between protein and 13-Methoxymatrine (CHEMBL1672134).

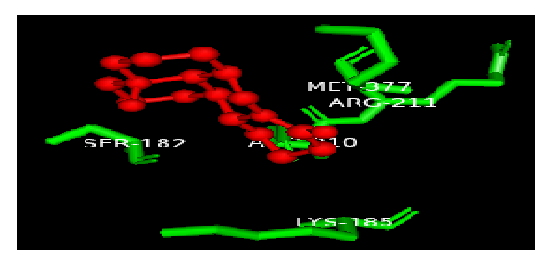

Fig. 15 3D interaction between protein and Oxymatrine.

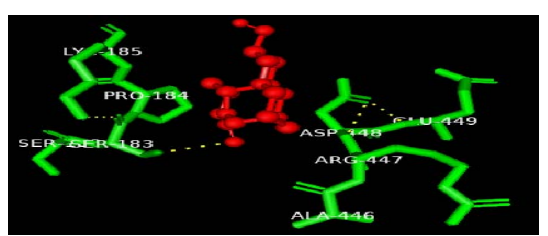

Fig. 16 3D interaction between protein and 9alpha-Hydroxymatrine (CHEMBL204747).

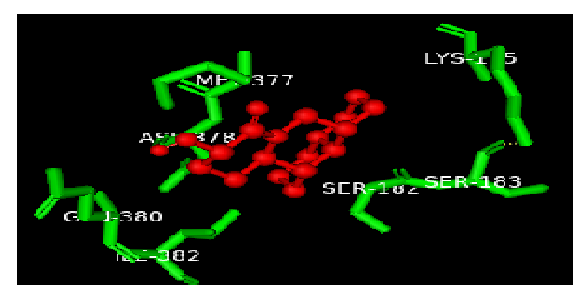

Fig. 17 3D interaction between protein and 14beta-Hydroxymatrine (CHEMBL3590539).

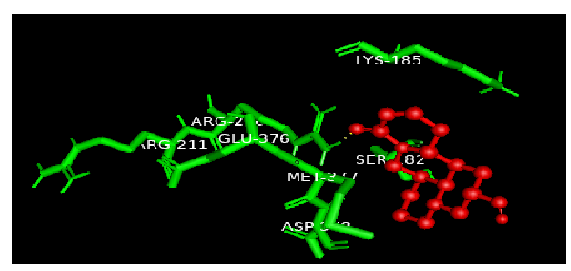

Fig. 18 3D interaction between protein and 9alpha-Hydroxy-13,14-didehydromatridine-15-one (CHEMBL382625).

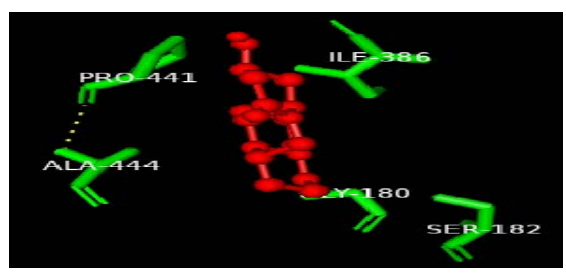

Fig. 19 3D interaction between protein and 13-Hydroxymatrine (CHEMBL1672133). 
A comprehensive study against Neuropathic Pain in human

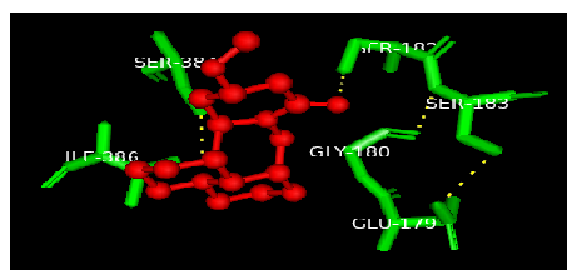

Fig. 20 3D interaction between protein and 13-Methoxymatrine (CHEMBL1672134).

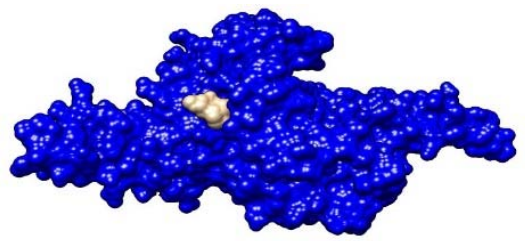

Fig. 21 Interaction between protein (blue color) and top lead (13-Methoxymatrine) (grey color).

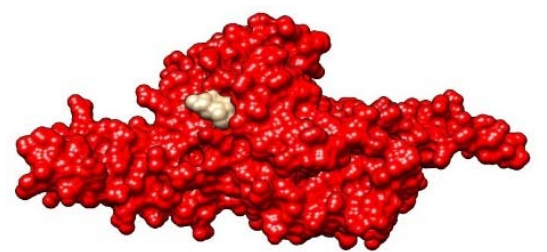

Fig. 22 Interaction between protein (red color) and top lead (13-Methoxymatrine) (grey color).

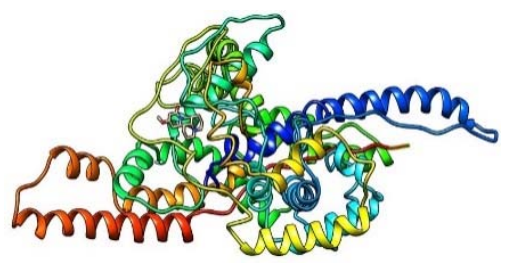

Fig. 23 Interaction between protein (ribbon style) and top lead (13-Methoxymatrine) (wire- frame style).

\subsection{Molecular properties and Oral toxicity prediction}

To get the prediction of pharmacokinetics properties of the lead compound 13-Methoxymatrine and mother ligand Oxymatrine, the SwissADME server was used and results are shown in Table 7. The toxicity and ADME profile of the lead compound 13Methoxymatrine and Oxymatrine were predicted by PreADMET server which is presented in Tables 8 and 9.

To develop an effective drug $\mathrm{BBB}$ is a major obstacle and BBB inhibits entrance most of the drug in the brain [53]. It was found that about $98 \%$ of the drugs fail to reach the market only for their insufficient BBB permeability [54]. Our lead (13Methoxymatrine) and mother compound
(Oxymatrine) both have the ability of BBB penetration Tables 7 and 8. A drug should have the capability of passing through the biological membranes, most importantly through human intestinal mucosa, which has a crucial role in the drug development methodology and for getting regulatory approval [55] and for the approval of novel and effective oral drug, understanding the transportation system of the drug through the membrane of intestine (large and small) is also prerequisite [56-61] and our lead as well as mother drug also positive in this crite- ria. Another major barrier towards successful absorption of any drug candidate is whether it is able to act as a substrate for Pglycoprotein (P-gp) or not which is an efflux membrane transporter and limits cellular uptake of a 
A comprehensive study against Neuropathic Pain in human

drug [62]. Our proposed lead (13-Methoxymatrine) predicted as Non-P-gp substrate which demands some optimization while mother ligand Oxymatrine predicted as P-gp substrate. Due to the difficulty and costly nature of human intestinal permeability [63], Caco- 2 or human colon carcinoma cell line is frequently used for screening permeability of drug candidates in the intestine [64]. But there is a considerable amount of conflicts between the Caco-2 permeability and measured the amount of HIA (human intestinal absorption) or permeability in the human intestine [65, 66]. In accordance with this, it is opined that biases or variability is introduced by in silico datasets as measurements of permeability is done from diverse laboratories and ambiguous information may be generated in terms of drug design [64]. It was predicted that our proposed lead (13Methoxymatrine) has high Caco-2 permeability while mother compound (Oxymatrine) has medium Caco-2 permeability and for this, a wet lab experiment is deserved to quantify whether this lead has a good penetrability through Caco- 2 or not.

In terms of metabolism of drugs, cytochrome P450 has significant clinical drug-drug interactions. There are about 30 isoenzymes of cytochrome P-450 in human are identified and among them CYP1A2, CYP2C, CYP2D6, and CYP3A4 sub-family have a major role in the metabolism of drug [67].

Table 7. Predicted Pharmacokinetics profile by SwissADME server of lead compound (13-Methoxymatrine) and mother compound (Oxymatrine).

\begin{tabular}{|c|c|c|}
\hline Pharmacokinetic id & 13-Methoxymatrine & Oxymatrine \\
\hline GI absorption & High & High \\
\hline BBB & Yes & Yes \\
\hline P-gp substrate & No & Yes \\
\hline CYP1A2 inhibitor & No & No \\
\hline CYP2C19 inhibitor & Yes & No \\
\hline CYP2C9 inhibitor & No & No \\
\hline CYP2D6 inhibitor & Yes & No \\
\hline
\end{tabular}

Table 8. Predicted ADME profile by PreADMET server of lead compound (13-Methoxymatrine) and mother compound (Oxymatrine).

\begin{tabular}{|l|c|c|}
\hline \multicolumn{1}{|c|}{ ADME id } & 13-Methoxymatrine & Oxymatrine \\
\hline $\begin{array}{l}\text { in vivo blood-brain barrier penetration } \\
\text { (C.brain/C.blood) }\end{array}$ & 1.04102 & 0.331105 \\
\hline $\begin{array}{l}\text { Water solubility in buffer system (SK atomic types, } \\
\text { mg/L) }\end{array}$ & 128153 & 5604.53 \\
\hline in vitro Caco-2 cell permeability (nm/sec) & 51.926 & 28.3155 \\
\hline in vitro CYP 2C19 inhibition & Non & Non \\
\hline in vitro CYP 2C9 inhibition & Non & Non \\
\hline in vitro CYP 2D6 inhibition & Non & Weakly \\
\hline in vitro CYP 2D6 substrate & Weakly & Non \\
\hline in vitro CYP 3A4 inhibition & Non & Weakly \\
\hline in vitro CYP 3A4 substrate & Weakly & 94.543733 \\
\hline Human intestinal absorption (HIA, \%) & 99.531077 & 0.786916 \\
\hline in vitro MDCK cell permeability (nm/sec) & 3.09133 & Non \\
\hline in vitro P-glecoprotein inhibition & Non & 13.270315 \\
\hline in vitro plasma protein binding (\%) & 35.005786 & 623160 \\
\hline Water solubility in pure water (SK atomic types, mg/L) & 39473.8 & -5.13011 \\
\hline in vitro skin permeability (logKp, cm/hour) & -3.9893 & -2.667040 \\
\hline SK logD in pH 7.4 (SK atomic types) & -1.017320 & -2.667040 \\
\hline SK logP (SK atomic types) & 0.547140 & -1.675320 \\
\hline SK logS in buffer system (SK atomic types, S: mol/L) & -0.336930 & 0.370740 \\
\hline SK logS in pure water (SK atomic types, S: mol/L) & -0.848350 & \\
\hline
\end{tabular}

Table 9. Predicted toxicity profile by PreADMET server of lead compound (13-Methoxymatrine) and mother compound (Oxymatrine). 
bioRxiv preprint doi: https://doi.org/10.1101/2021.11.03.467110; this version posted November 4, 2021. The copyright holder for this preprint (which was not certified by peer review) is the author/funder, who has granted bioRxiv a license to display the preprint in perpetuity. It is made available under aCC-BY 4.0 International license.

A comprehensive study against Neuropathic Pain in human

\begin{tabular}{|c|c|c|}
\hline Toxicity ID & 13-Methoxymatrine & Oxymatrine \\
\hline Algae at & 0.155566 & 0.223082 \\
\hline Ames test & non-mutagen & Mutagen \\
\hline Carcino Mouse & Negative & Negative \\
\hline Carcino Rat & Positive & Positive \\
\hline Daphnia at & 1.71284 & 4.87941 \\
\hline hERG inhibition & Low risk & Low risk \\
\hline
\end{tabular}

Overall, our proposed lead (13-Methoxymatrine) and mother com- pound (Oxymatrine) are good enough in this case but demands some optimization as well as some wet lab experiments for ensuring the predicted value is accurate.

In terms of toxicity profile, our proposed lead is AMES non-mutagen. Our proposed lead (13Methoxymatrine) predicted as non-mutagen crosses this barrier and mother ligand predicted as mutagen. Though, there are some critiques regarding AMES test. As in AMES test, rat liver S9 fraction is used and there are considerable amount of differences between rat and human metabolism regarding the mutagenic effect of chemicals and it is strongly recommended to use human liver S9 fraction instead of rat S9 in AMES test for assessing genotoxicity to humans [68]. For this, our lead (13Methoxymatrine) also requires a wet lab experiment for evaluating whether it is toxic or non-toxic to human.

Failure of drug candidates during developmental stage accounts for about $20 \%$ due to toxic properties [69]. It is estimated that during the preclinical development stage, $54 \%$ failures occurred due to safety and toxicity concern which was responsible for US $\$ 1.8$ billion/marketed drug [70]. It was found that the use of animals in trial phase were 100-200 million, 60- 85 million and 50-100 million in 1970, 1993 and 2005 respectively [71]. A statistic showed that over 29 million animals were used for clinical trials only in North American and European countries [72]. In this situation, in silico methods for predicting the toxicity of a drug candidate can be used which will not only reduce time and cost but also save the lives of millions of animals [73]. PreADMET server predicted that our top lead (13-Methoxymatrine) and mother ligand (Oxymatrine) were negative in terms of carcinogenic in mouse as well as had low risk in terms of hERG inhibition.

\section{CONCLUSION}

In this current study, we have keyed out a potential drug candidate against VGF which is responsible for the regulation of metabolism, reproduction, gastric contractility, mood regulation, and peripheral neuropathic pain in human.

The compound 13-Methoxymatrine is an antagonist for VGF. This molecule has shown some good properties than the current mother ligand oxymatrine which is also a potential VGF inhibitor. The new molecule has also promising docking scores in the active site of the target VGF compared to oxymatrine. Additionally, this compound showed a good toxicity profile with some confusions in ADMET properties which require some wet lab experiments to verify the real scenario.

These analyses demonstrate that our proposed drug candidate can be a good choice of option for treating the peripheral neuropathic pain caused by VGF. Furthermore, evaluation in the wet lab is obligatory for getting regulatory approval of a drug candidate.

However, these findings provide a consolidated suggestion that our proposed lead can be a drug candidate and could be used as drug template for the treatment of peripheral neuropathic pain caused by VGF in human.

\section{LIST OF ABBREVIATIONS}

ADMET- absorption, distribution, metabolism, and excretion - toxicity in pharmacokinetics

AMES test- a test to determine the mutagenic activity of chemicals. BBB-blood brain barrier

BLAST - Basic Local Alignment Search Tool

CADD-Computer-aided drug discovery

ChEMBL- Biological database

COMT- Catechol-O-Methyltransferase

CYP2D6- Cytochrome P450 2D6

EMBL - European Molecular Biology Laboratory

HEK cells - Human embryonic kidney cells HGMD-

Human Gene Mutation Database

$\mathrm{kDa}$ - kilodaltons

KOR - $\kappa$-opioid receptor

MAOA- Monoamine Oxidase A

MDCK- Madin-Darby Canine Kidney (MDCK) cells

MOR- $\mu$-opioid receptor 
bioRxiv preprint doi: https://doi.org/10.1101/2021.11.03.467110; this version posted November 4, 2021. The copyright holder for this preprint (which was not certified by peer review) is the author/funder, who has granted bioRxiv a license to display the preprint in perpetuity. It is made available under aCC-BY 4.0 International license.

A comprehensive study against Neuropathic Pain in human

NCBI -National Centre for Biotechnology Information

OMTR-Oxymatrine

PDB - Protein Data Bank

PDBQT- Protein Data Bank, Partial Charge (Q), \& Atom Type (T) format

PreADMET- web-based application for predicting ADME data

UCSC - University of California, Santa Cruz OPRM1,

UCSF - University of California, San Francisco

\section{CONFLICT OF INTEREST}

The authors declare no conflict of interest, financial or otherwise.

\section{ACKNOWLEDGEMENTS}

The authors are highly acknowledged and express their gratitude to late Dr. Md. Shamim Akhter for his high support and motivation.

\section{REFERENCES}

[1] Bartolomucci, A., Possenti, R., Mahata, S., Fischer-Colbrie, R., Loh, Y. and Salton, S., 2011. The Extended Granin Family: Structure, Function, and Biomedical Implications. Endocrine Reviews, 32(6), pp.755-797.

[2] Hunsberger, J. G., Newton, S. S., Bennett, A. H., Duman, C. H., Russell, D. S., Salton, S. R., \& Duman, R. S. (2007). Antidepressant actions of the exercise-regulated gene VGF. Nature medicine, 13(12), 1476-1482.

[3] Thakker-Varia, S.; Jean, Y.Y.; Parikh, P.; Sizer, C.F.; Ayer, J.J.; Parikh, A.; Hyde, T.M.; Buyske, S.; Alder, J. The neuropeptide VGF is reduced in human bipolar postmortem brain and contributes to some of the behavioral and molecular effects of lithium. $J$ Neurosci 2010, 30, 9368-80.

[4] Tv, S.; K, J.N.. J.; Bilimoria, P.M.; Bangasser, D.A.; Shors, T.J.; Black, I.B.; Alder, J. The neuropeptide VGF produces antidepressantlike behavioral effects and enhances proliferation in the hippocampus. $J$ Neurosci 2007, 27, 12156-67.

[5] Watson, E.; Fargali, S.; Okamoto, H.; Sadahiro, M.; Gordon, R.E.; Chakraborty, T.; Salton,; ., S.R. Analysis of knockout mice suggests a role for VGF in the control of fat storage and energy expenditure. $B M C$ physiology 2009, 9, 19-19.

[6] Veber, D. F., Johnson, S. R., Cheng, H. Y., Smith, B. R., Ward, K. W., \& Kopple, K. D. (2002). Molecular properties that influence the oral bioavailability of drug candidates. Journal of medicinal chemistry, 45(12), 2615-2623.

[7] Akhter, S. (2015). Isolation of VGF derived neuropeptide receptor.

[8] Akhter, S., Chakraborty, S., Moutinho, D., Álvarez-Coiradas, E., Rosa, I., Vinuela, J., ... \& Requena, J. R. (2017). The human VGFderived bioactive peptide TLQP-21 binds heat shock $71 \mathrm{kDa}$ protein 8 (HSPA8) on the surface of SH-SY5Y cells. PloS one, 12(9).

[9] Ling, J. Y., Zhang, G. Y., Cui, Z. J., \& Zhang, C. K. (2007). Supercritical fluid extraction of quinolizidine alkaloids from Sophora flavescens Ait. and purification by high-speed counter-current chromatography. Journal of Chromatography A, 1145(1-2), 123-127.

[10] Wang, Y.P.; Liu, F.; He, H.W.; Han, Y..; Peng, Z.G.; Li, B.W.; You, X.F.; Song, D.Q.; Li, Z.R.; Yu, L.Y.; Cen, S.; Hong, B.; Sun, C.H.; Zhao, L.X.; Kreiswirth, B.; Perlin, D.; Shao, R.G.; Jiang, J.D. Antimicrob Agents Chemother 2010, 5, 2070-2077.

[11] Pruitt, K. D., Tatusova, T., \& Maglott, D. R. (2005). NCBI Reference Sequence (RefSeq): a curated non-redundant sequence database of genomes, transcripts and proteins. Nucleic acids research, 33(suppl_1), D501-D504.

[12] Johnson, M.; Zaretskaya, I.; Raytselis, Y.; Merezhuk, Y.; Mcginnis, S.; Madden, T.L. NCBI BLAST: a better web interface. Nucleic acids. research 2008, 36, 9-9.

[13] Kuntal, B. K., Aparoy, P., \& Reddanna, P. (2010). EasyModeller: A graphical interface to MODELLER. BMC research notes, 3(1), 226.

[14] Guex, N., \& Peitsch, M. C. (1997). SWISS $\square$ MODEL and the Swiss $\square \mathrm{Pdb}$ Viewer: an environment for comparative protein modeling. electrophoresis, 18(15), 2714-2723.

[15] Schwede, T.; Kopp, J.; Guex, N.; Peitsch, M.C. SWISS-MODEL: an automated protein homology- modeling server. Nucleic acids. research 2003, 31, 3381-3385. 
[16] Kiefer, F., Arnold, K., Künzli, M., Bordoli, L., \& Schwede, T. (2008). The SWISSMODEL Repository and associated resources. Nucleic acids research, 37(suppl_1), D387D392.

[17] Nielsen, M., Lundegaard, C., Lund, O., \& Petersen, T. N. (2010). CPHmodels-3.0remote homology modeling using structureguided sequence profiles. Nucleic acids research, 38(suppl_2), W576W581.NUSSER, Z., SIEGHART, W. \& SOMOGYI, P. 1998.

[18] Luthy, R.; Bowie, J.U.; Eisenberg, D. Assessment of protein models with threedimensional profiles. Nature 1992, 6364, 8385.

[19] Arnold, K., Bordoli, L., Kopp, J., \& Schwede, T. (2006). The SWISS-MODEL workspace: a web-based environment for protein structure homology modelling. Bioinformatics, 22(2), 195-201.

[20] Laskowski, R.A.; Macarthur, M.W.; Moss, D.S.; Thornton, J.M. PROCHECK: a program to check the stereochemical quality of protein structures. Journal of applied crystallography 1993, 2, 283-291.

[21] Benkert, P.; Biasini, M.; Schwede, T. Toward the estimation of the absolute quality of individual protein structure models. Bioinformatics 2010, 3, 343-350.

[22] Pettersen, E.F.; Goddard, T..; Huang, C.C.; Couch, G.S.; Greenblatt, D.M.; Meng, E.C.; Ferrin, T.E. UCSF Chimera-a visualization system for exploratory research and analysis. Journal of computational chemistry 2004, 13, 1605-1612.

[23] Farhadi, T.; Fakharian, A.; Ovchinnikov, R.S.; Gaulton, A.; Bellis, L.J.; Bento, A.P.; Chambers, J.; Davies, M.; Hersey, A. Virtual screening for potential inhibitors of CTX-M15 protein of Klebsiella pneumoniae. Interdisciplinary Sciences: Computational Life Sciences 2011, 10, 694-703.

[24] Gaulton, A., Bellis, L. J., Bento, A. P., Chambers, J., Davies, M., Hersey, A., . . . Al-Lazikani, B. (2011). ChEMBL: a largescale bioactivity database for drug discovery. Nucleic acids research, 40(D1), D1100-D1107.

[25] Daina, A.; Michielin, O.; Zoete, V. SwissADME: a free web tool to evaluate pharmacokinetics, drug-likeness and medicinal chemistry friendliness of small molecules. Scientific Reports 2017,7.

[26] Ghose, A.K.A.G..; Viswanadhan, V.N.; Jj, W.D. Journal of combinatorial chemistry 1999, 1, 55-68.

[27] Lipinski, C.A.; Lombardo, F.; Dominy, B.W.; Feeney, P.J. Experimental and computational approaches to estimate solubility and permeability in drug discovery and development settings. reviews 1997, 23, 1-3. Advanced drug delivery.

[28] Egan, W.J.; Merz, K.M.; Baldwin, J.J.) see absorption using multivariate statistics. Journal of medicinal chemistry 2000, 21, 3867-3877

[29] Muegge, I. Selection criteria for drug-like com- pounds. Medicinal research reviews 2003, 3, 302-321.

[30] Lagunin, A.; Stepanchikova, A.; Filimonov, D.; Poroikov, V. PASS: prediction of activity spectra for biologically active substances. Bioinformatics 2000, 8, 747-748.

[31] Sander, T.; Freyss, J.; Korff, M.; Rufener, C. DataWarrior: an open-source program for chemistry aware data visualization and analysis. Journal of chemical information and modeling 2015, 2, 460-473.

[32] Trott, O.; Olson, A.J. AutoDockVina: improving the speed and accuracy of docking with a new scoring function, efficient optimization, and multi- threading. Journal of computational chemistry 2010, 2, 455-461.

[33] Wallace, A. C., Laskowski, R. A., \& Thornton, J. M. (1995). LIGPLOT: a program to generate schematic diagrams of proteinligand interactions. Protein engineering, design and selection, 8(2), 127-134.

[34] Seeliger, D.; Groot, B.L. Ligand docking and binding site analysis with PyMOL and Autodock/Vina. Journal of computer-aided molecular 2010, 5, 417-422.

[35] Lill, M.A.; Danielson, M.L. Computer-aided drug design platform using PyMOL. Journal of computer-aided molecular 2011, 1, 13-19.

[36] Shin, H. K., Kang, Y. M., \& No, K. T. (2016). Predicting ADME properties of chemicals. In Handbook of Computational Chemistry (pp. 1-37). Springer Publisher.

[37] Hossain, S.S.; Zhang, Y.; Liang, X.; Hussain, F.; Ferrari, M.; Hughes, T.J.; Decuzzi, P. In silico vascular modeling for personalized nanoparticle delivery. Nanomedicine 2013, 8 , 343-357.

[38] Josa, D.; Cunha, E.F.; Ramalho, T.C.; Souza, 
A comprehensive study against Neuropathic Pain in human

T.C.; Caetano, M.S. Homology modeling of wild-type, D516V, and H526L Mycobacterium tuberculosis RNA polymerase and their molecular docking study with inhibitors. Journal of Biomolecular Structure and Dynamics 2008, 25, 373-376.

[39] Mohan, S.S.; Perry, J.; Poulose, N.; Nair, B.G.; Anilkumar, G. Homology modeling of GLUT4, an insulin regulated facilitated glucose transporter and docking studies with ATP and its inhibitors. Journal of Biomolecular Structure and Dynamics 2009, 4, 455- 464.

[40] Sujatha, K.; Mahalakshmi, A.; Solaiman, D.K.; R, S.G. Journal of Biomolecular Structure and Dynamics 2009, 6, 771-779.

[41] Martí-Renom, M. A., Stuart, A. C., Fiser, A., Sánchez, R., Melo, F., \& Šali, A. (2000). Comparative protein structure modeling of genes and genomes. Annual review of biophysics and biomolecular structure, 29(1), 291-325.

[42] Chen, Y.C.; Pristerá, A.; Ayub, M.; Swanwick, R.S.; Karu, K.; Hamada, Y.; Okuse, ..; ., K. Identification of a receptor for neuropeptide VGF and its role in neuropathic pain. Journal of Biological Chemistry 2013, 288, 3463834646.

[43] Ghose, A. K., Viswanadhan, V. N., \& Wendoloski, J. J. (1999). A knowledge-based approach in designing combinatorial or medicinal chemistry libraries for drug discovery. 1. A qualitative and quantitative characterization of known drug databases. Journal of combinatorial chemistry, 1(1), 55-68.

[44] Muegge, I.; Heald, S.L.; Brittelli, D. Simple selection criteria for drug-like chemical matter. Journal of medicinal chemistry 2001, 12, 1841-1846.

[45] Clark, D.E.; Pickett, S.D. Computational methods for the prediction of 'drug-likeness. Drug discovery. today 2000, 5, 49-58.

[46] Lipinski, C.A. Drug-like properties and the causes of poor solubility and poor permeability. methods 2000, 44, 235-249. Journal of pharmacological and toxicological.

[47] Walters, W.P.; Murcko, A.A.; Murcko, M.A. Recognizing molecules with drug-like properties. Current opinion in chemical. biology 1999, 3, 384-387.

[48] Teague, S. J., Davis, A. M., Leeson, P. D., \& Oprea, T. (1999). The design of leadlike combinatorial libraries. Angewandte Chemie International Edition, 38(24), 3743-3748.
[49] Kumar, D.T.; Lavanya, P.; Doss, C.; Tayubi, I.A.; Ku- Mar.; Drn.; Yesurajan, I.F.; Balaji, V. A molecular docking and dynamics approach to screen potent inhibitors against fosfomycin resistant enzyme in clinical Klebsiella pneumoniae. Journal of cellular 2017.

[50] Sneha, P.; Doss, C. Chapter SevenMolecular Dynamics: New Frontier in. Personalized Medicine Advances in 2016, 102, 181-224.

[51] Malathi, K., \& Ramaiah, S. (2016). Molecular docking and molecular dynamics studies to identify potential OXA-10 extended spectrum $\beta$-Lactamase nonhydrolysing inhibitors for pseudomonas aeruginosa. Cell biochemistry and biophysics, 74(2), 141-155.

[52] Sehgal, S. A., Hassan, M., \& Rashid, S. (2014). Pharmacoinformatics elucidation of potential drug targets against migraine to target ion channel protein KCNK18. Drug design, development and therapy, 8, 571.

[53] Alavijeh, M. S., Chishty, M., Qaiser, M. Z., \& Palmer, A. M. (2005). Drug metabolism and pharmacokinetics, the blood-brain barrier, and central nervous system drug discovery. NeuroRx, 2(4), 554-571.

[54] Geldenhuys, W.J.; Allen, D.D.; Bloomquist, J.R. Novel models for assessing blood-brain barrier drug permeation. Expert opinion on drug metabolism. \& 2012, 6, 647-653.

[55] Testa, B.; Caldwell, J. Prodrugs revisited: the "ad hoc" approach as a complement to ligand design. Medicinal research reviews 1996, 3 , 233-241

[56] Davis, S., \& Wilding, I. (2001). Oral drug absorption studies: the best model for man is man! Drug discovery today, 6(3), 127-130.

[57] Lennernäs, H.; Abrahamsson, B. The use of bio-pharmaceutic classification of drugs in drug discovery and development: current status and future extension. Journal of Pharmacy and Pharmacology 2005, 3, 273285.

[58] Hinderling, P.H.P.H..; Karara, A.H.; Tao, B.; Pawula, M.; Wilding, I. Tract The Journal of Clinical Pharma- cology 2007, 1, 19-25.

[59] Porter, C.J.; Trevaskis, N.L.; Charman, W.N. Nature Reviews Drug Dis 2007, 3, 231-248.

[60] Ungell. Membrane transport of drugs in different regions of the intestinal tract of the 
A comprehensive study against Neuropathic Pain in human

rat. Journal of pharmaceutical sciences $\mathbf{1 9 9 8 ,}$ $3,360-366$.

[61] Watson, E.; Fargali, S.; Okamoto, H.; Sadahiro, M.; Gordon, R.E.; Chakraborty, T.; Salton, ..; ., S.R. Analysis of knockout mice suggests a role for VGF in the control of fat storage and energy expenditure. $B M C$ physiology 2009, 9, 19-19.

[62] Amin, M.L. P-glycoprotein inhibition for optimal drug delivery. Drug target insights 2013, 7, 12519-12519

[63] Larregieu, C. A., \& Benet, L. Z. (2013). Drug discovery and regulatory considerations for improving in silico and in vitro predictions that use Caco-2 as a surrogate for human intestinal permeability measurements. The AAPS journal, 15(2), 483-497.

[64] Artursson, P., Palm, K., \& Luthman, K. (2001). Caco-2 monolayers in experimental and theoretical predictions of drug transport. Advanced drug delivery reviews, 46(1-3), 2743.

[65] Benet, L.; Larregieu, C. The FDA should eliminate the ambiguities in the current BCS biowaiver guidance and make public the drugs for which BCS biowaivers have been granted. Clinical Pharmacology \& Therapeutics 2010, 3, 405-407.

[66] Yang, Y., Faustino, P. J., Volpe, D. A., Ellison, C. D., Lyon, R. C., \& Yu, L. X. (2007). Biopharmaceutics classification of selected $\beta$-blockers: solubility and permeability class membership. Molecular pharmaceutics, 4(4), 608-614.

[67] Michalets, E.L. Update: clinically significant cytochrome P-450 drug interactions.
Pharmacotherapy. The Journal of Human Pharmacology and Drug Therapy 1998, 1, 84-112.

[68] Hakura, A.; Suzuki, S. Satoh T. Mutation Research/Genetic. Toxicology and Environmental Mutagenesis 1999, 1, 29-36.

[69] Muster, W.; Breidenbach, A.; Fischer, H.; Kirchner, S.; Müller, L.; Pähler, A. Computational toxicology in drug development. Drug discovery. today 2008, 13, 303-310.

[70] Segall, M.D.; Barber, C. Addressing toxicity risk when designing and selecting compounds in early drug discovery. Drug discovery. today 2014, 5, 688-693.

[71] Taylor, K., Gordon, N., Langley, G., \& Higgins, W. (2008). Estimates for worldwide laboratory animal use in 2005.

[72] Reinhardt, V., \& Reinhardt, A. (2006). Variables, refinement and environmental enrichment for rodents and rabbits kept in research institutions: Animal Welfare Institute.

[73] Drwal, M. N., Banerjee, P., Dunkel, M., Wettig, M. R., \& Preissner, R. (2014). ProTox: a web server for the in silico prediction of rodent oral toxicity. Nucleic acids research, 42(W1), W53-W58. 


\section{List of Figures}

1 The modeled protein in ribbon style.

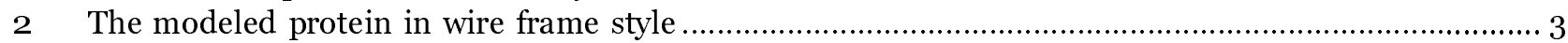

3 The modeled protein in hydrophobocity surface style ................................................................ 4

4 Ramachandran plot of modeled structure validated by PROCHECK server ......................................... 4

$5 \quad$ Validation of the modeled structure by QMEAN6.................................................................................. 4

6 Superimposed structure of the modeled protein and templates................................................... 5

7 Superimposed structure of the modeled protein (blue colour) and template (3j83.1.A) (red colour).......

8 Superimposed structure of the modeled protein (blue colour) and template (2i1j) (green colour)......... 5

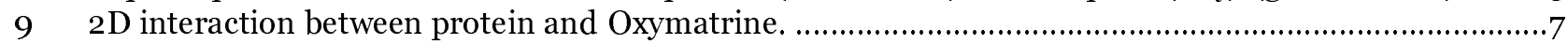

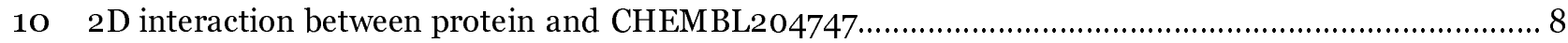

11 2D interaction between protein and CHEMBL3590539................................................................ 8

12 2D interaction between protein and CHEMBL382625.................................................................... 8

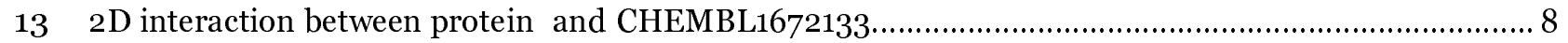

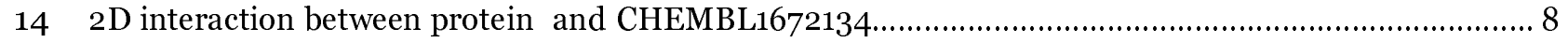

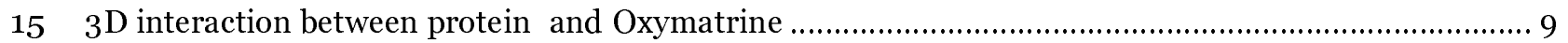

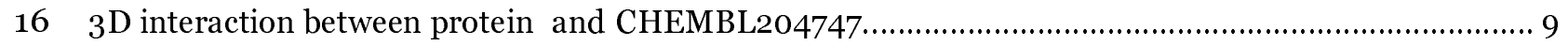

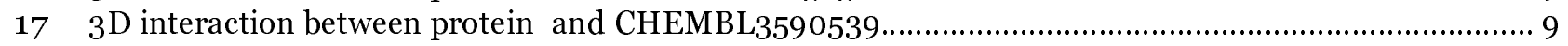

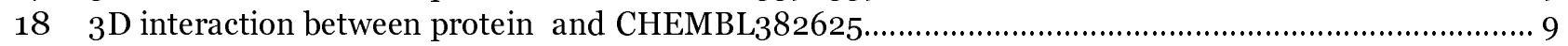

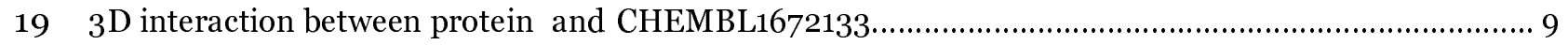

20 3D interaction between protein and CHEMBL1672134 .......................................................................9

21 Interaction between protein(blue colour)and top lead (CHEMBL1672134) (grey colour)....................10

22 Interaction between protein(red colour)and top lead (CHEMBL1672134) (grey colour).......................10

23 Interaction between protein(ribbon style) and top lead (CHEMBL1672134) (wire frame style)............10 



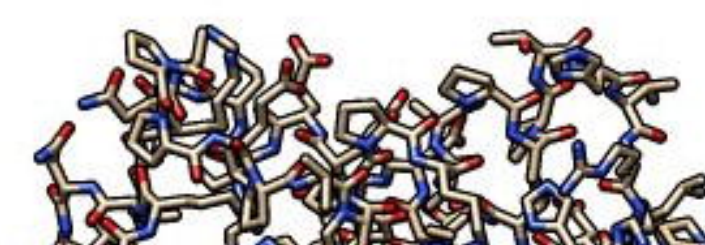
10. \& 5 an

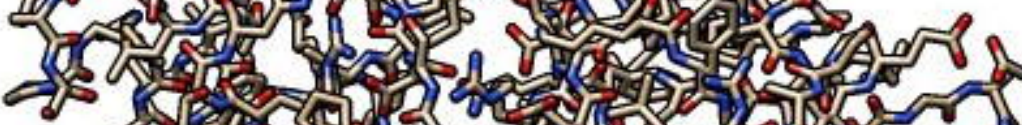

S.

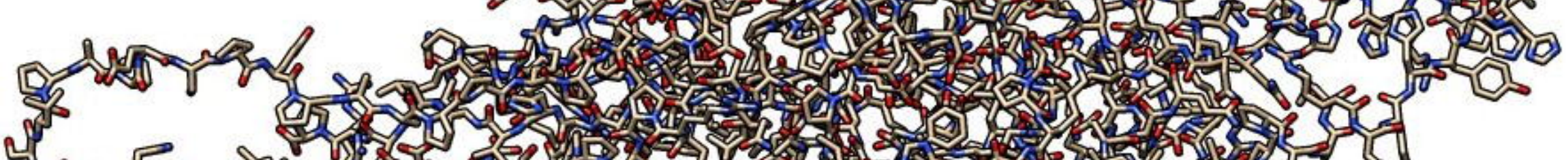

4

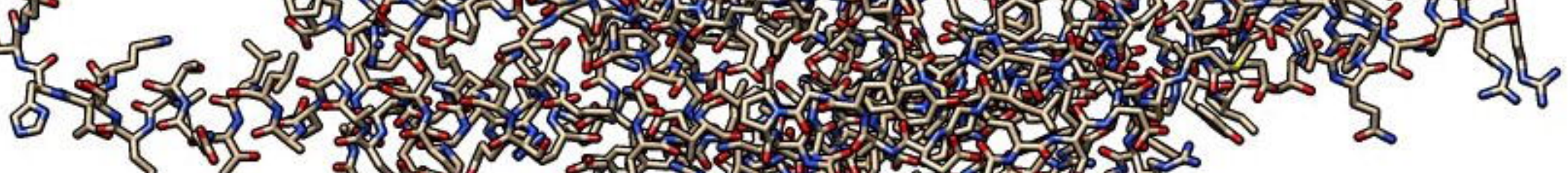

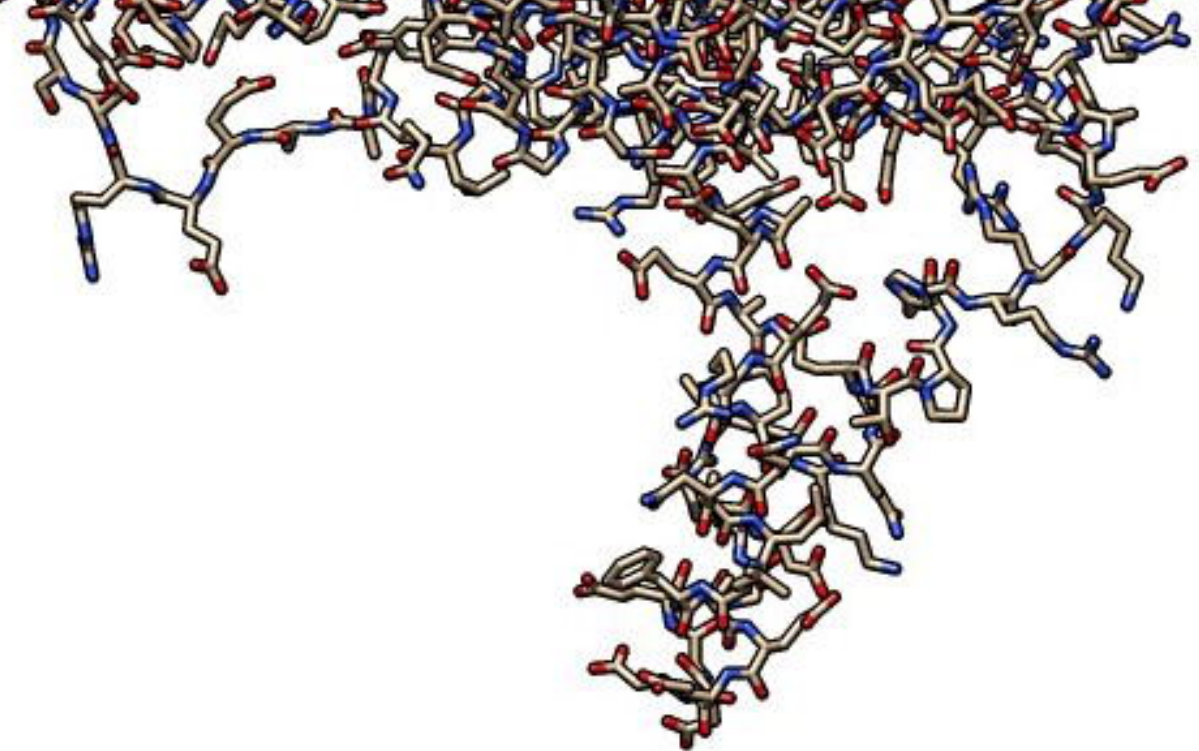




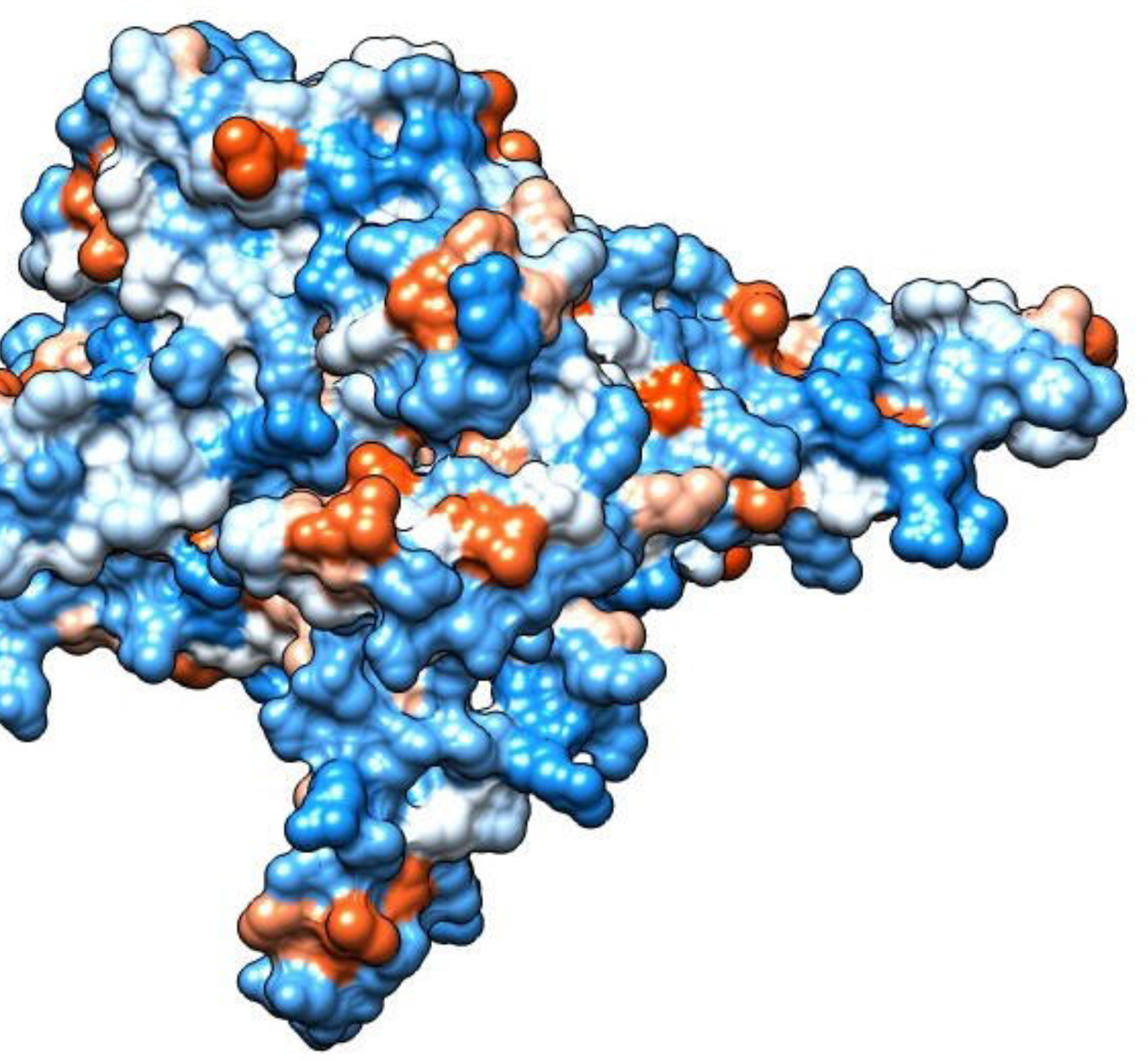


Papqaca.

\section{Ramachandran Plot 9015702}

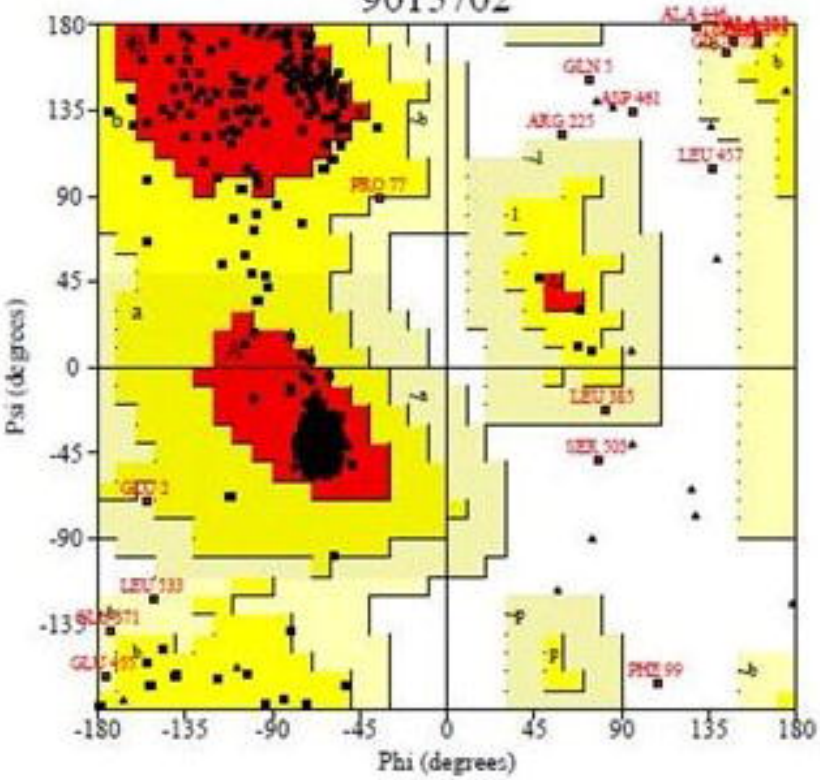




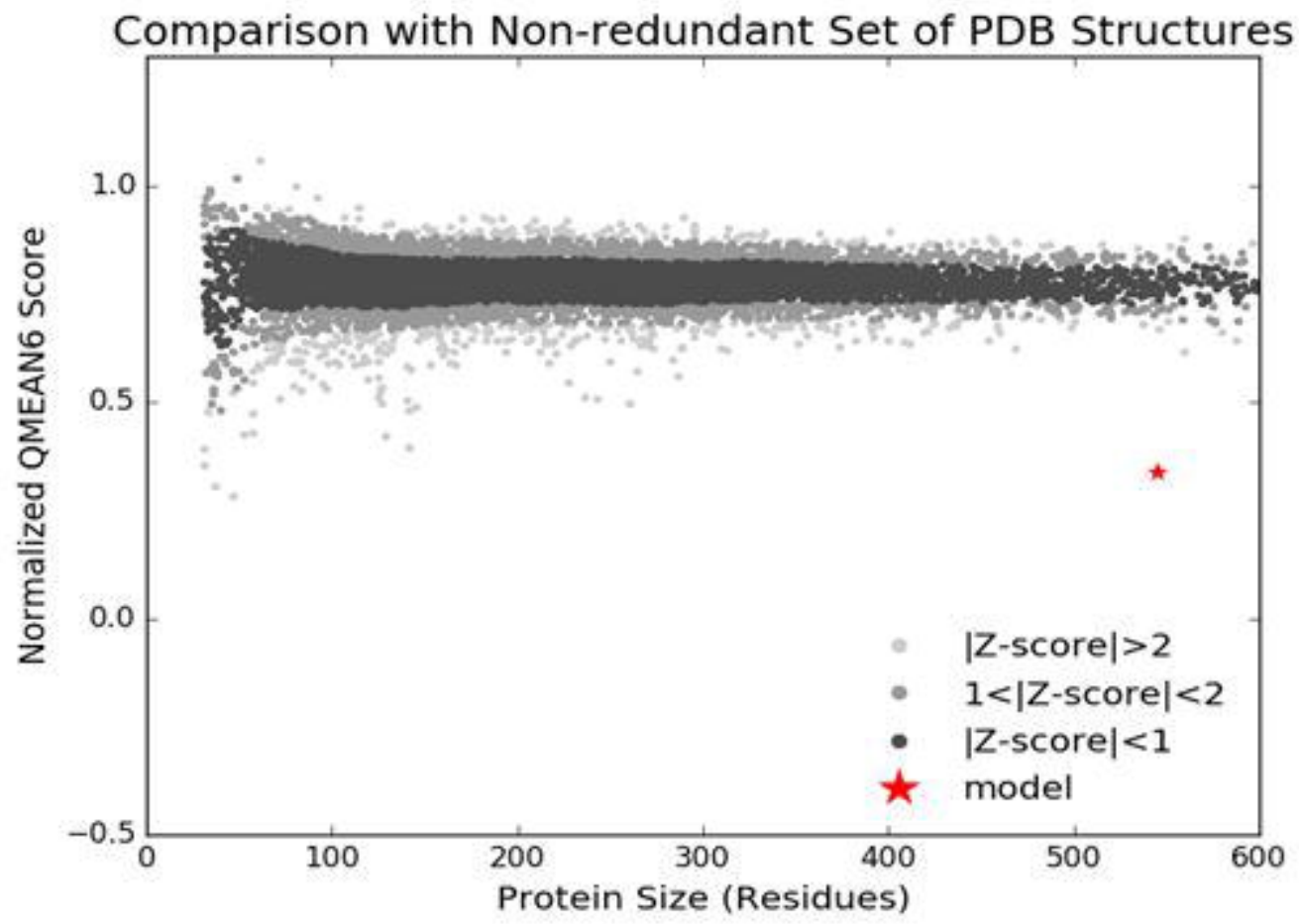




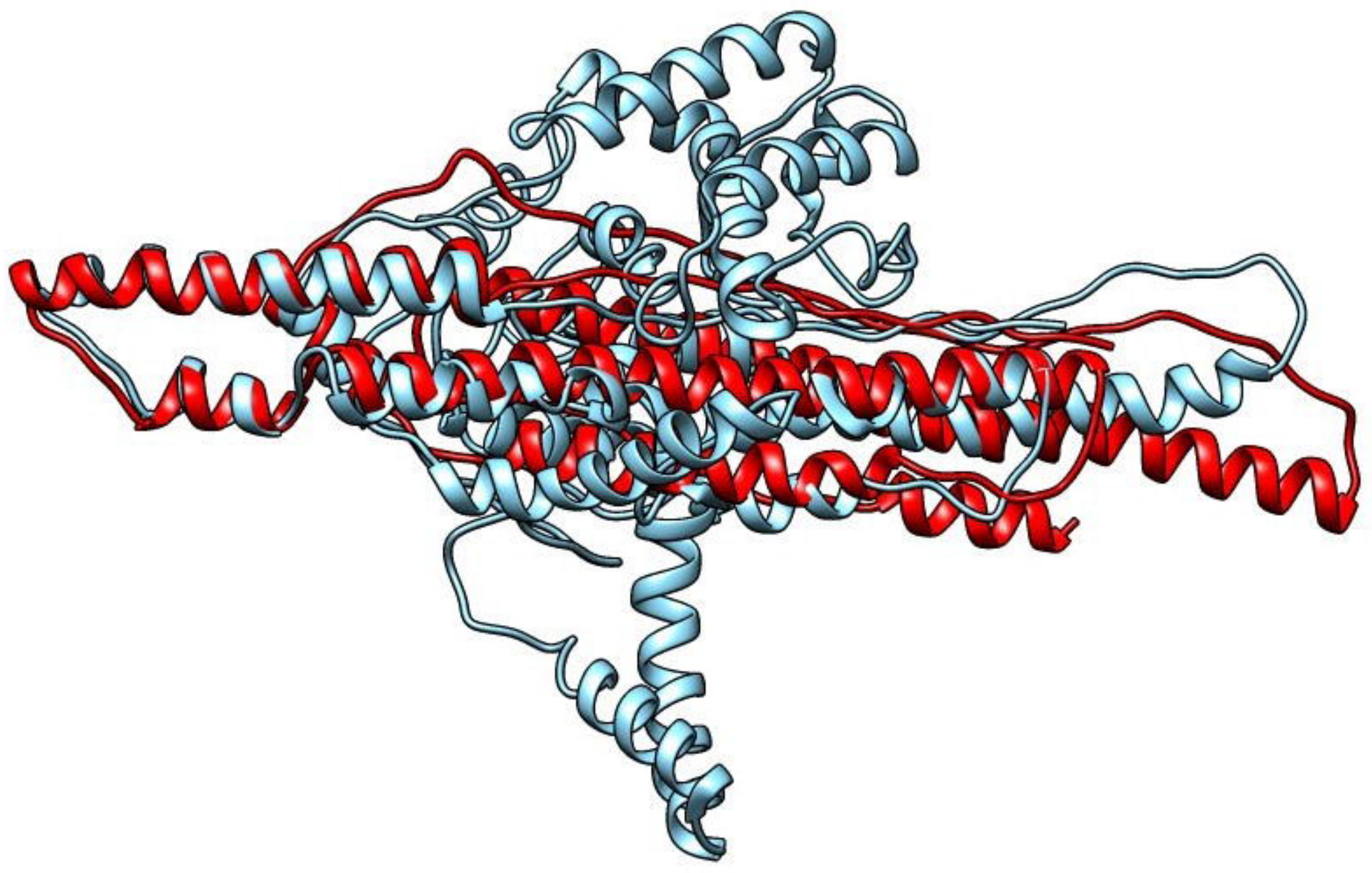





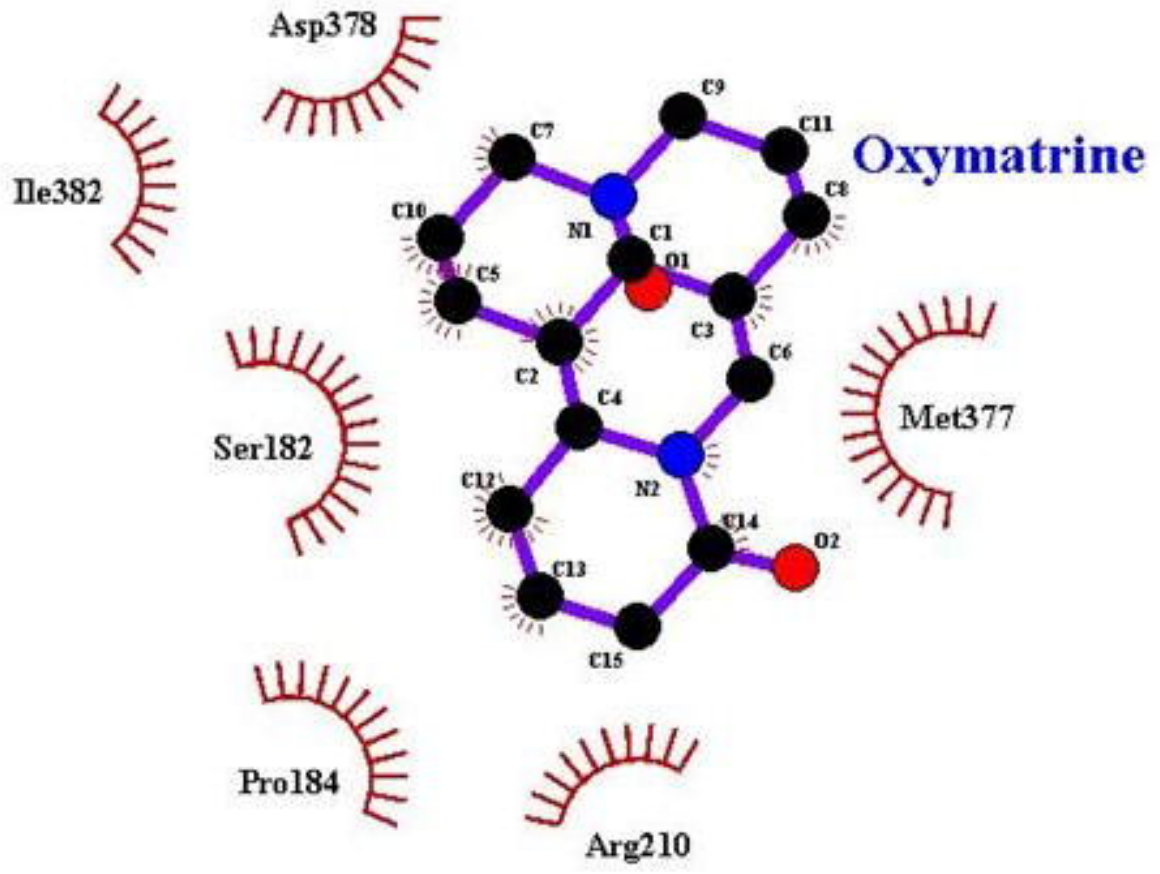




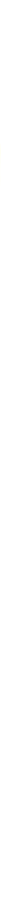




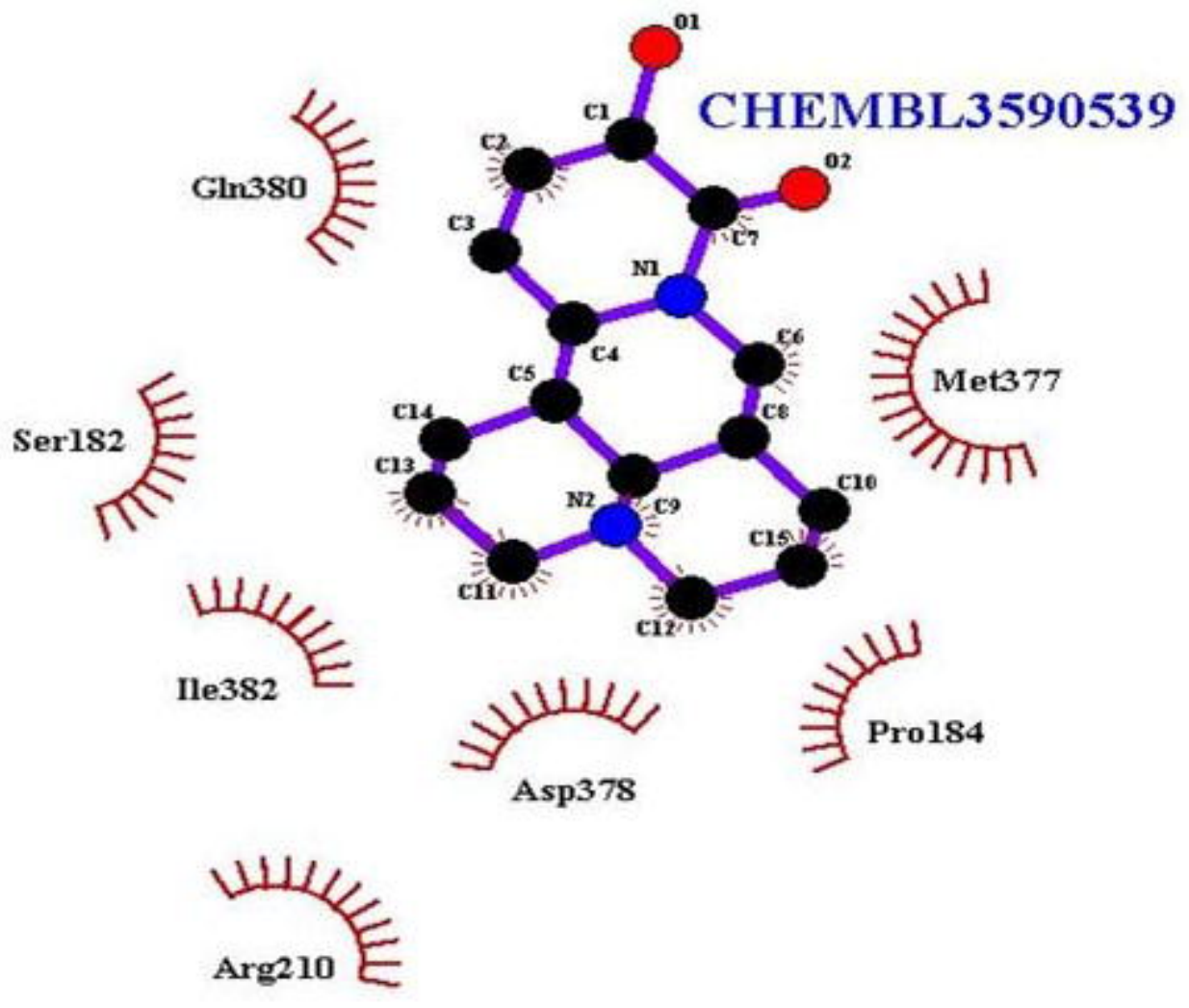




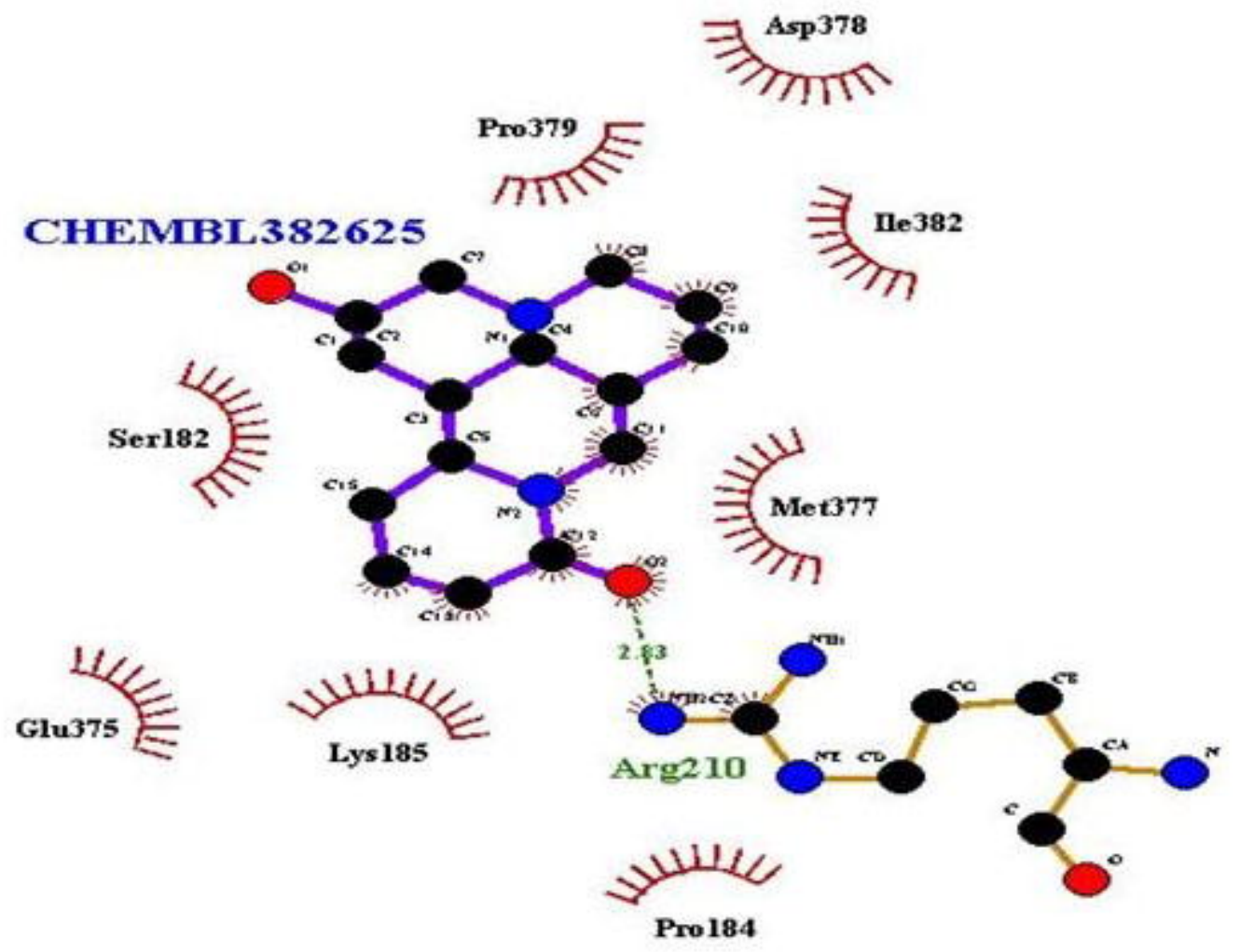




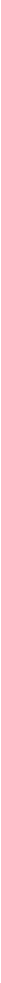





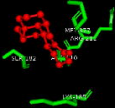




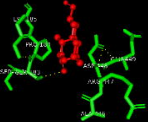




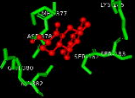




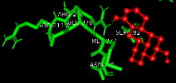




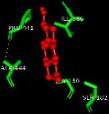




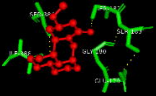




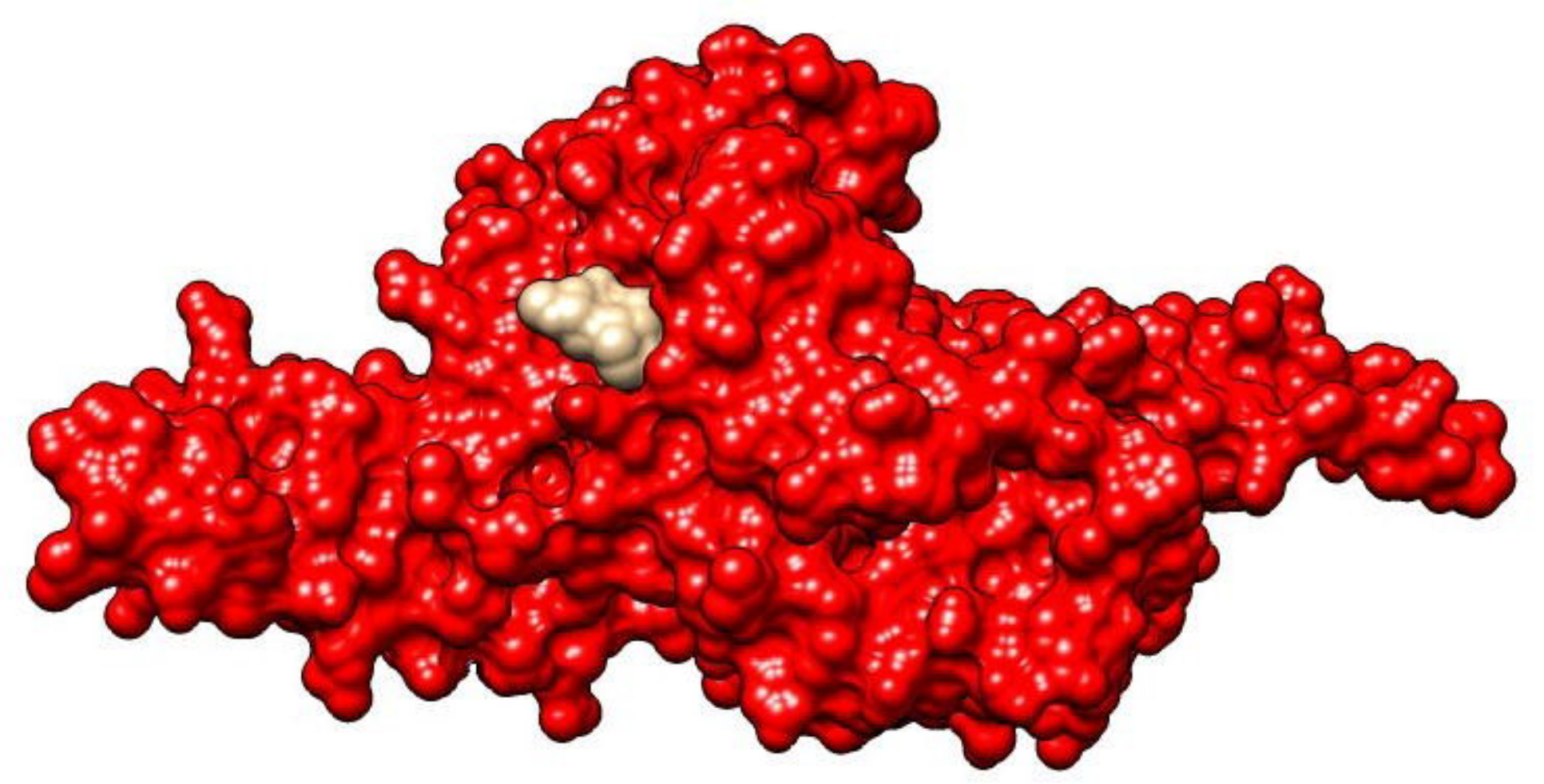




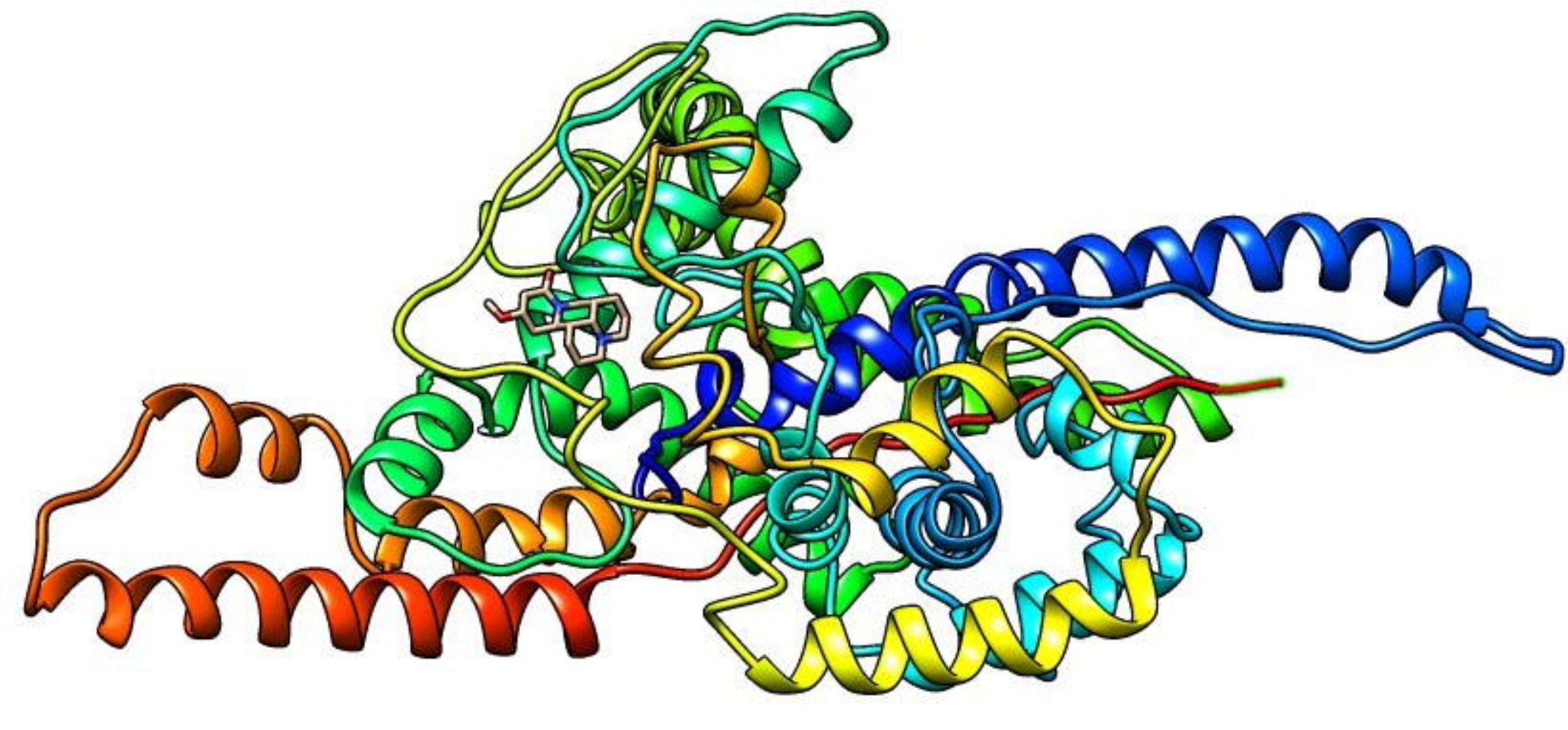

